


\title{
Sustainability by improving energy efficiency in traditional housing in Kosovo
}

\author{
Elvida Pallaskal, Tore Haugen², Visar Hoxha ${ }^{3}$, Luca Finochiaro ${ }^{4}$, \\ Alenka Temeljotov Salaj,
}

\begin{abstract}
The objective to this paper is to identify and evaluate aspects of sustainability by improving energy efficiency of traditional housing in Kosovo. The fact that refurbishment of them is to be more rational, as for sustainable and consistent use of the houses- sustainable occupancy, as for sustainable environmental protection, sustainable tourism, good practice to young urban planners, architects and real estate managers.

It is acknowledged that master artisans of traditional architecture in Kosovo were conscious of the sustainability parameters in designing and constructing the traditional houses in villages and rural areas. Efficiency in the use of space, smart building location and orientation, design of the buildings, functionality of inner spaces, lay out of window openings and use of materials have been important for the traditional old buildings. Traditional housing today, does not fulfil the needs and requirements regarding energy efficiency and comfort, as there is not sufficient insulation and heating systems. Rational use of space in neighbourhood creation, density within the city, connectivity with other neighbourhoods and the rest of the city, accessibility, careful approach to surrounding/environment, rational orientation of neighbourhood enabling as well ventilation of the city, should also be identified as part of the sustainable urban development.

KEYWORDS: sustainability, energy efficiency, traditional housing refurbishment, passive design, inner city rehabilitation,
\end{abstract}

\footnotetext{
${ }^{1}$ ESLG-Kosovo, PHD- elvida.pallaska@gmail.com ;

${ }^{2}$ NTNU-Norway, Prof. Dr., tore.haugen@ntnu.no

${ }^{3}$ ESLG - Kosovo, Prof. Dr. visar.hoxha@gmail.com

${ }^{4}$ NTNU-Norway, Prof. Dr. luca.finocchiaro@ntnu.no

${ }^{5}$ EFL-Slovenia, Prof.Dr. alenka.temeljotov-salaj@ntnu.no
} 


\section{Table of contents}

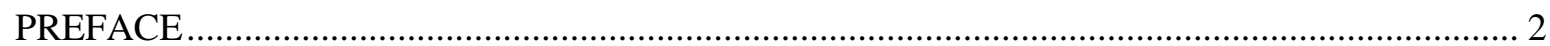

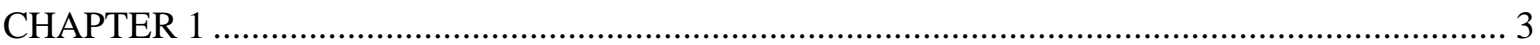

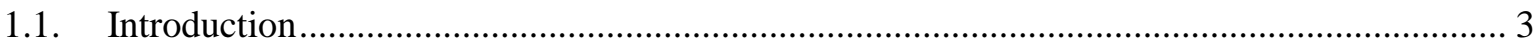

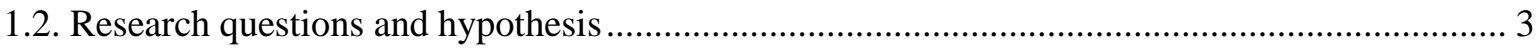

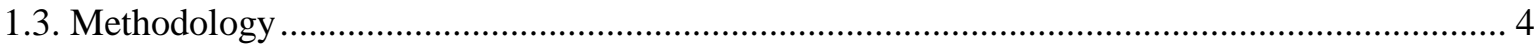

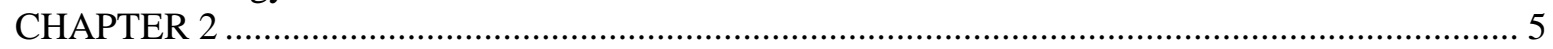

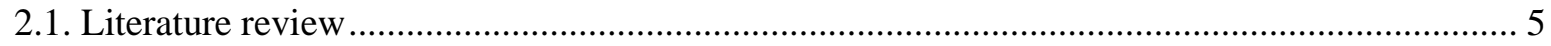

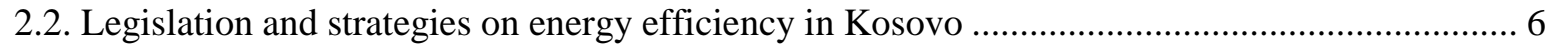

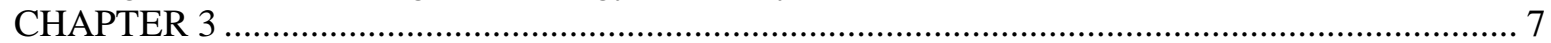

3.1. Analyses on urban planning and architectural design of the neighbourhood/ traditional

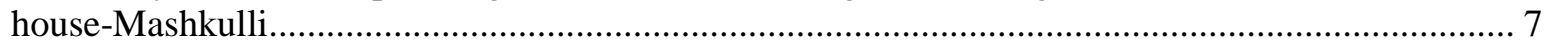

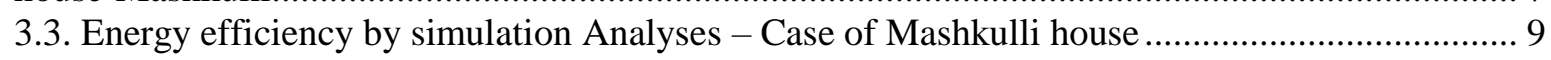

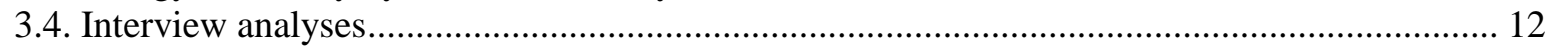

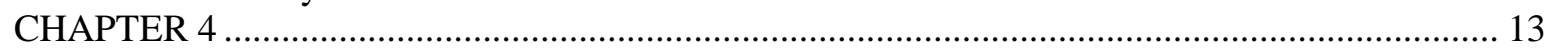

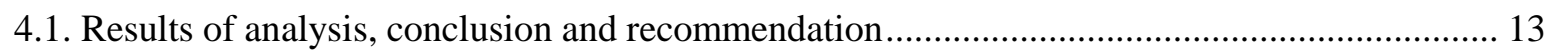

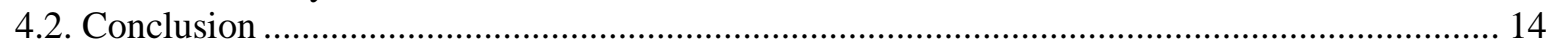

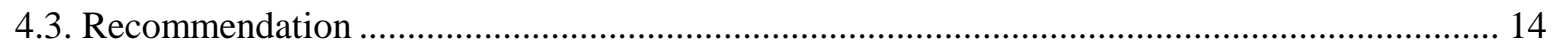

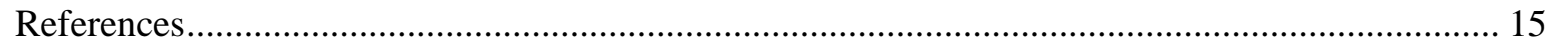

\section{PREFACE}

This paper is prepared in the framework of joint cooperation project "SEEB - Sustainable Energy Efficient Buildings" between Kosovo and Norway, by which has been carried out case studies of existing traditional houses to find relevant and suitable measures to improve the energy efficiency and indoor comfort in the traditional houses. Through energy analysis of refurbishment, we have found recommendations for solutions for energy improvements by passive design. The needs for refurbishment have to take into account the historic values and sustainable qualities of the buildings and the historic urban areas.

The absolute majority of energy in Kosovo is used for residential needs. The absolute majority of houses in Kosovo, including old and new buildings, are not efficient. Furthermore, a large part of the houses and apartments in Kosovo use electrical energy for heating, causing energy efficiency to be at an alarmingly low level. Kosovo authorities have begun planning and drafting public policies related to efficiency based more on the requests made by the European Union rather than on the basic need for efficiency.

Prizren city in Kosovo, ancient city and full of history throughout centuries if not millennium, have in its core or central district, the historic nutshell composed of cultural heritage buildings, mainly of traditional houses but as well of public buildings. Houses are poorly inhabited and with the tendency to either be demolished and newly reconstructed or being left un inhabited, because of poor living conditions, poor living comfort. 


\section{CHAPTER 1}

\subsection{Introduction}

The main objective to this study is to analyze possible improvements of energy efficiency measures in traditional houses in Prizren city/Kosovo and compare them vs sustainability indicators, socio-economic and physical/environmental ones.

Improvements of energy efficiency in traditional houses in Prizren city, are seen as appropriate measures, toward reaching different other sustainable goals than of only comfort. This is seen as initial step, important and useful with big outcome results for the city, region, culture, economy etc.

Traditional houses in the city district core of the city of Prizren, by the last data from the Conservation Plan of the City of Prizren, 2007, where many of traditional houses have been demolished and left un- inhabited, for the main reason - to be newly rebuilt. The main driver to these actions are due to higher economic income benefits to the owners of the houses, when renting new house. The design of new ex-traditional houses do not obey on the traditional design and architecture, this is the threat as said by the owner-interviewe to this tudy : "there is lost of the cultural heritage, lost of the city spirit" (Int. \#7, 2015).

The refurbishment of existing buildings is a neglected subject within sustainable architecture, where attention is usually focused on new buildings. Demolition is an option but the alternative of refurbishment is starting to be seen as more sustainable in terms of architectural value, materials use, neighbourhood disruption and waste disposal. Building new is more carbon intensive and carries many wider environmental impacts. In addition, the potential impact of low energy refurbishment is much greener than that of new build, since there are many more existing buildings that will be built in the next 10-20 years, the period over which many $\mathrm{CO} 2$ emission targets apply, (Baker, 2009)

\subsection{Research questions and hypothesis}

The main research questions are:

1. Does by improving energy efficiency in traditional housing would be reached sustainable solution in economic, social and physical/environmental aspect?;

2. Does legislation in Kosovo supports improvement of energy efficiency in traditional housing as solution and development strategy?;

3. What do the key people of Prizren, think about energy improvement of traditional housing in Prizren/Kosovo as potential towards sustainable urban development of Kosovo cities?

I - The first hypothesis that is based on the climate and envelope data is "A traditional Albanian house (such as house Mashkulli), is nowadays not energy efficient due to poor thermal properties, but the use of both passive and active strategies can improve the environmental and energy performance of the building."

II - The second hypothesis is: "By improving energy efficiency in traditional housing in Kosovo/Prizren city, would be reached sustainable solution in economic, social and physical/environmental aspect of development". 


\subsection{Methodology}

The research is a qualitative and exploratory study. Analysis of the city of Prizren's current historic core district profile, strategic documents on conservation/refurbishment; National legislation and strategy document on Energy Efficiency; Simulation analysis of the energy efficiency of the traditional case -house, by modelling it in Design Builder ${ }^{6}$; and at the end in total 30 interviews were conducted with well informed key people of Prizren regarding traditional housing in core historic centre of Prizren: i)inhabitants; ii)municipal officials; iii) civil society representatives with the open-ended questions.

The desk part of the research has been conducted in terms of:

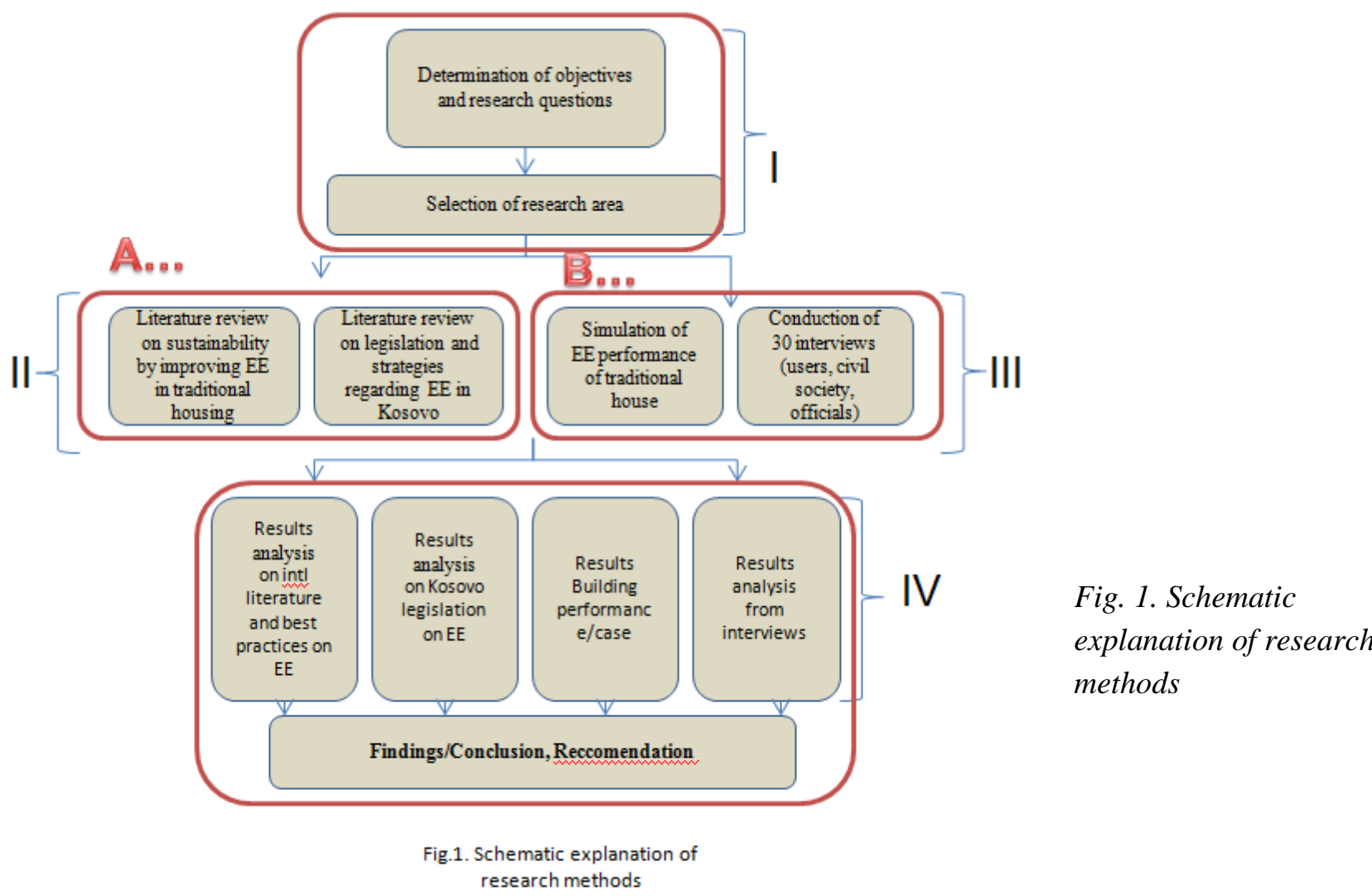

A.I. Literature review, based theories and best practices on: Economic, social and environmental impacts of refurbishment vs rebuild, improvement of energy efficiency in traditional housing, building performance, passive design, sustainable urban development, inner city rehabilitation;

A.II. Legislation and strategy documents review on Energy Efficiency in Kosovo;

The empirical part of the research has been conducted in terms of:

B.I. Simulation analyses of a case traditional house on building performance in historical core district center of Prizren (Mashkulli house). The building was modelled in Design Builder. U-values of the elements were calculated assuming the thermal properties of the existing building.

B.II. Interview analyses: 30 in depth interviews were conducted and their analysis. The main driver to these interviews was finding their opinion on the potentials towards sustainable solution of the urban development of

6 DesignBuilder Software Ltd, 2015. DesignBuilder (v 4.5.0.173). [computer program] DesignBuilder Software Ltd. Available at: <http://www.designbuilder.co.uk/> [Accessed October 2015] 
Prizren by improving energy efficiency in traditional housing in core historic central district of the city of Prizren. The research methodology is explained at Fig 1.

Data sources - Types of data being used as for this research are divided into two groups, theoretical and empirical part:

- Data for theoretical part of the study on i) Sustainable refurbishment, Strategies for low emission refurbishment, energy use in traditional housing, environmental comfort standards, and passive environmental strategies; ii)

- Data for the empirical part of the study as: Conservation Plan of the historic core Prizren city district; Building detail design plan of the traditional case-Mashkulli house, and interviews.

\subsection{Research paper structure}

This research paper has four chapters. Chapter 1 - presents elaborated objectives, research questions, hypothesis and the methodology; Chapter 2 presents -2.1 . Reviewed literature on theories and best practices on improvement of energy efficiency in traditional housing, building performance, passive design, sustainable urban development; 2.2. Legislation and strategy documents review on Energy Efficiency of Kosovo; Chapter 3 presents 3.1. Urban planning analyses of neighbourhood; 3.2. Energy efficiency simulation analyses of a case study of Mashkulli traditional house; 3.3. Interview analyses; Chapter 4 presents Results of all analyses; conclusion and recommendation.

\section{CHAPTER 2}

\subsection{Literature review}

This chapter contains: i) Literature review on definitions such as sustainable development, sustainable refurbishment and passive design toward energy efficiency of traditional houses etc; ii) Review of Legislation and Strategies of Kosovo regarding Energy efficiency.

Urban development of historic cities is very challenging, especially when it comes to inner city rehabilitation, where is composed of historic nutshell. This is due to the need for more rational use of space on behalf of redevelopment, but in the other aspect of traditional buildings that needs refurbishment as for continuation of use, measure of conservation though are seen as more costly. Therefore at this chapter we would paraphrase the definitions and best practices of concepts such as sustainable development first of all, that are conditioned with the measures taken in built environment, i.e. architecture.

Sustainable development- It is clear that no move towards sustainable development can go ahead without radical changes in architecture, construction and spatial planning, a huge drive to conserve energy, increase efficiency and create zero-carbon buildings, all of which are vital in reducing the environmental impacts of buildings. (Häkkinen, 2012)

Urban development - (non)cautious exploitation of resources - Planning a sustainable society requires a holistic approach in which we learn from and cooperate with nature. We can take from this some fundamental principles for environmental sustainability, including: renewable resources must be managed in a sustainable way; non-renewable resources must be recycled; air, water and soil need to be kept clean and biodiversity has to be maintained. (Bokalders and Block, 2010)

Sustainable society- (non)cautious lifestyle - Transition to sustainable technology and renewable energy sources is not enough to achieve sustainable development. Needed to change lifestyle, , eg. if all of the people in the world had a lifestyle similar to the average person in the European Union, four planet Earths would be needed to satisfy everyone's energy and resource needs. (Bokalders and Block, 2010)

Environmental cities- Cities are the focal point of the energy use and at the same time, the solution to energy efficiency and reduction of pollution. Conventional wisdom about the environmental impact of cities holds urbanization and environmental quality at odds: "Building sector of today has an oversized ecological footprint, 
being single largest contributor to global greenhouse gas emissions and responsible for more than a third of global resource consumption". (Meyer, 2013)

Green buildings and residential retrofit -As per Baeli, 2013, housing stock in Europe, represents oldest in Europe with 55\%. Rising levels of greenhouses gases, mainly $\mathrm{CO} 2$, are increasingly becoming a concern for most of the world's governments. Residential buildings are also part of the solution too, where retrofit is not only about participating in the reduction of $\mathrm{CO} 2$ emissions, but as well avoiding the dilapidation of buildings that have become uninhabitable, helping to future-proof houses against the risks of fuel poverty and, last but not least, providing comfort for occupants.

What would be solution? - Continuing as per Baeli, 2013, the challenge consists on what can be done with existing buildings, ensuring their use in continuation, including financial investment to avoid dilapidation, ensuring their representativeness, cultural identity and at the same time delivering the levels of reduction in energy use.

Retrofit option rather than demolition and complete rebuild is more recommended for the following reasons: i) Societal point of view - retrofit seems to be more acceptable than complete rebuild; It could also potentially create long-term employment; Replacement of degraded finishes and components; Tailoring space organization to new uses; Improving environmental quality.

Implications for change of use - As per Baker, 2009, refurbishment is often accompanied by change of use. Change of use may bring about changes in purely technical parameters. Change of use may bring about an increase in the energy consumption. This does not necessarily mean that the low energy refurbishment has failed, since the measures adopted have undoubtedly led to lower energy consumption than if absent.

\subsection{Legislation and strategies on energy efficiency in Kosovo}

In this section would be reviewed legislation and strategy documentation in Kosovo, from the perspective of enabling environment and support to the refurbishment of buildings, in a perspective of energy efficiency:

- The Kosovo Law on Energy Efficiency is compatible with EU legislation, specifically with reference to the Directives on energy efficiency for provision of necessary incentives and improvement of the energy efficiency in all consuming sectors ${ }^{7}$.

- Kosovo program for energy efficiency and renewable energy resources 2007-2009 provides the framework for the implementation of energy efficiency and renewable energy in Kosovo.

- National Energy Efficiency Plan of Kosovo, represents the first long-term energy efficiency plan which covers the period from 2008 till 2016, sets indicative target for energy saving for the period 2008-2016, (based on the article 4(1) of Directive 2006/32/EC). Short and long term target for energy saving in residential sector based on the revised NEEP is presented in the figure below:

- Draft Law on energy performance of buildings - Represents still law in drafting phase, where promotion of improvements to the energy performance of buildings, taking into account outdoor climatic and local conditions, as well as indoor climate requirements and cost-effectiveness, in Kosovo.

- Policies for increasing energy efficiency-Some of the policies developed for the increase of efficiency in Kosovo that are related to the entry into force of the Administrative Instruction on the Labelling of Energy Products, the introduction of excise tax for inefficient light bulbs, mandatory application of energy efficiency measures related to the issuance of the utilisation permit for buildings, the increase in the price of electricity higher than $8.0 \%$ and application of block tariffs.

The challenges regarding Energy efficiency in Kosova are:

\footnotetext{
${ }^{7}$ The Directive 2004/8/EC, amending Directive 92/42/EEC aiming on saving energy and improving security of supply, Directive 2002/91/EC on the Energy performance of buildings and other important EU Directives on this field were taken into consideration
} 
- Implementation of Energy Efficiency measures not seen as priority of the government, where EE is seen as only a legislative "must" to fulfil, if tenting EU membership;

- When talking on EE, is mainly meant in alternative energy production;

- The power sector in Kosovo relies on only two thermal based on coal power-plant, that produces $97 \%$ of overall energy production, in paradox where Kosovo is looking forward to renewed economic growth, increased opportunities, and an enhanced quality of life arising in part from the development of the energy sector.

- Incomplete legal framework for energy efficiency in residential buildings;

- Incomplete technical regulation regarding energy efficiency and changes on existing regulation on thermal energy saving;

- Lack of human capacities at central and local level, lack of coordination between organizations;

- Lack of awareness raising campaigns, to help change the approach and understanding of the wider professional public which could draw attention to the importance of the necessary thermal energy savings in building sector in general;

- Lack of discussion to develop innovative financing for energy efficiency investments in residential buildings;

Challenges in Kosovo regarding Energy efficiency

\section{CHAPTER 3}

\subsection{Analyses on urban planning and architectural design of the neighbourhood/ traditional house-Mashkulli}

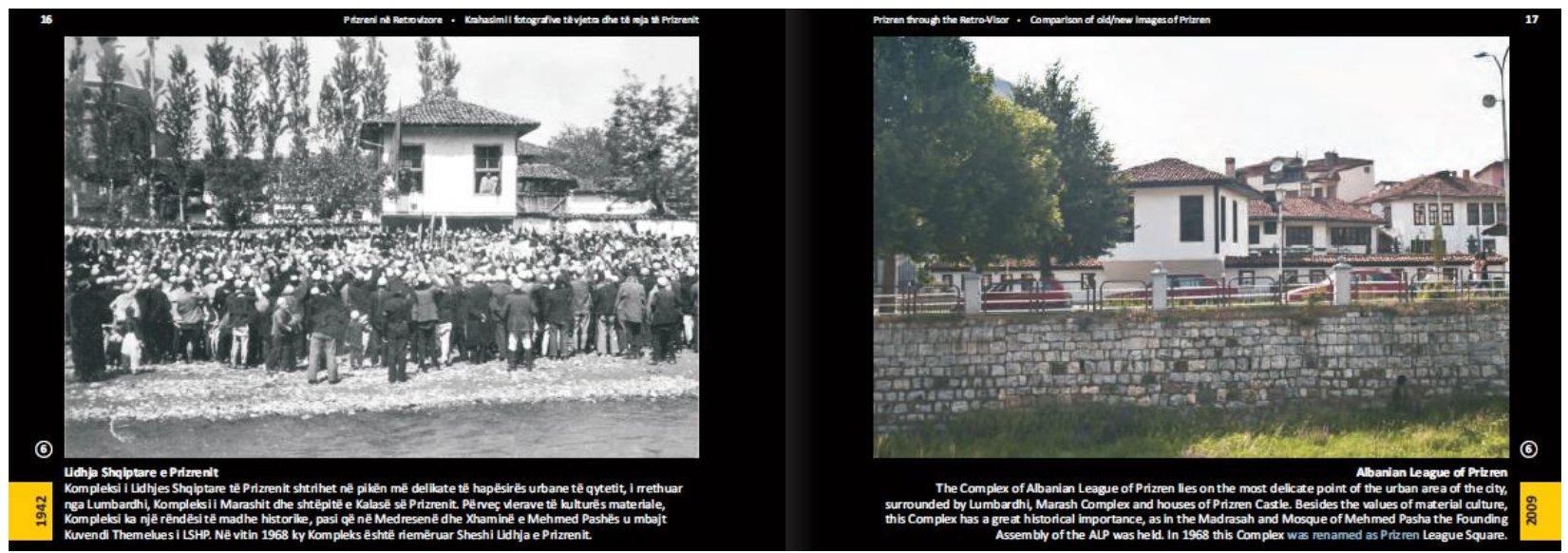

Fig. 2.. Before and after - neighbourhood of Mashkulli house, and water front development (Source, EC ma NDRYSHE, 2012)

Prizren is famous city for its old, traditional dwellings. Starting from the Castle called Kalaja, that dominates the city, urban landscape is enriched with numerous historic buildings. Prizren has several urban residences. The diversity of the town's inhabitants, influencing each other in social and cultural terms, had an impact on building and construction and the legacy of Byzantine and Ottoman culture during the 18th and 19th centuries is visible. Houses with a gallery are representative of the typical Albanian house, in comparison to other places in Balkans.

Climate - The Municipality of Prizren has an altitude of 412 - 500 m. It is surrounded by the National ParkSharri Mountains. The climate is predominantly continental climate, by its vicinity to the mountains, but in the 
other side the Mediterranean climate also reaches the city of Prizren due to the warm Adriatic draught that comes through the Drini i Bardhe River canyon.

Our chosen pilot project as mentioned above is the home of the family Mashkulli, an old building, of 19th (end of $18^{\text {th }}$ ) century, in the centre of Prizren, near the Bajrakli Mosques and Medrese, nowadays known as the League of Prizren. The Mashkulli family were traders in the past and the çardaku (closed gallery) was extended to the riverside, being converted into a number of shops, such as for a shoe maker.

Typology - Mashkulli House belongs to the Urban House typology, where other buildings in the house's yard were the selamllëk (guesthouse), destroyed during the 80 's, the harem and the çardak. The Mashkulli family were traders in the past and the çardaku (closed gallery) was extended to the riverside, being converted into a number of shops, such as for a shoe maker.

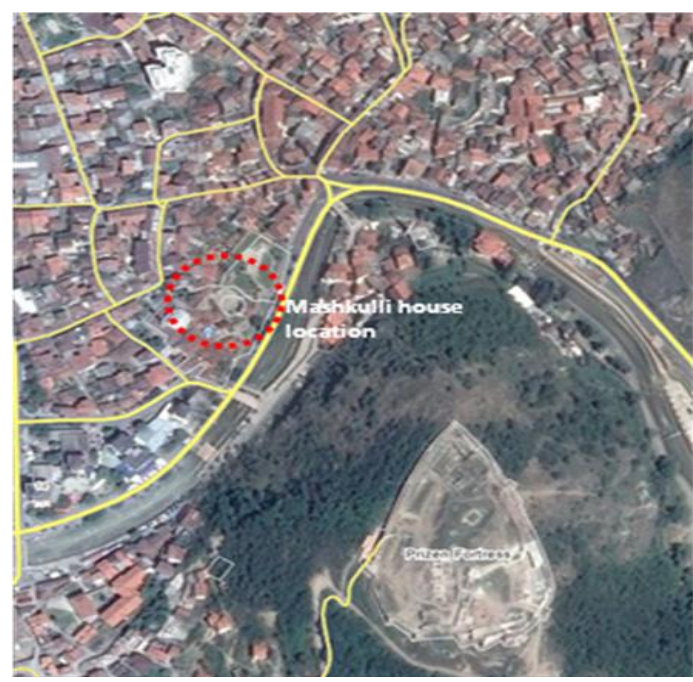

Fig. 3. Location of Mashkulli house

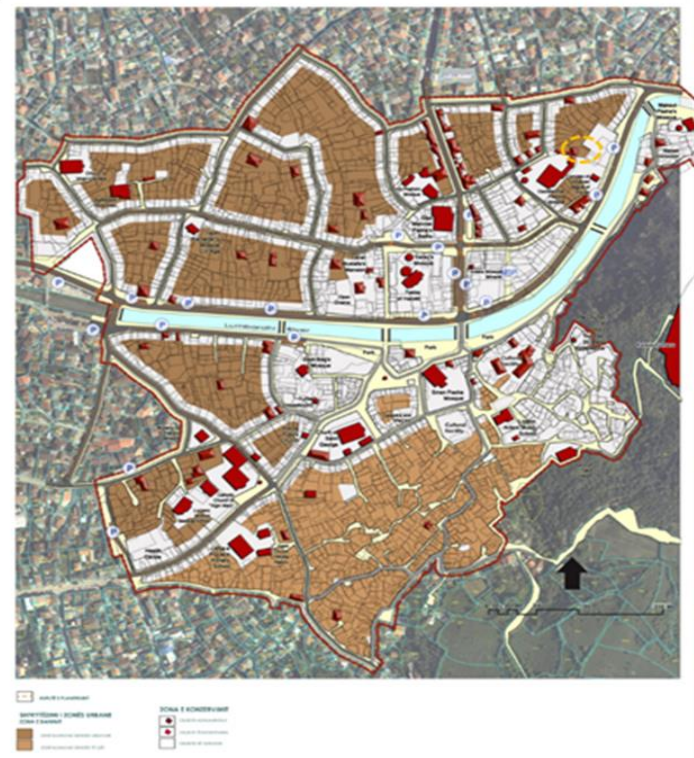

Fig. 4. Map from conservation Plan of Historic district of PrizrenFuture zoning /housing

Accessibility - The access road to the house is via the main road parallel with the river Lumbardhi, whereas the entrance to the house is from the public square of "Prizren League" - free and well organised from the southern side. Entrance into the house is via the private house garden, respecting green zoning of the neighbourhood.

Neighborhood context: Since the house's main entrance is via public square, furnished with qualitative public lighting, pedestrian path, public inventory. The house is next to the landmark of the city, important node that defines character of a neighbourhood/city.
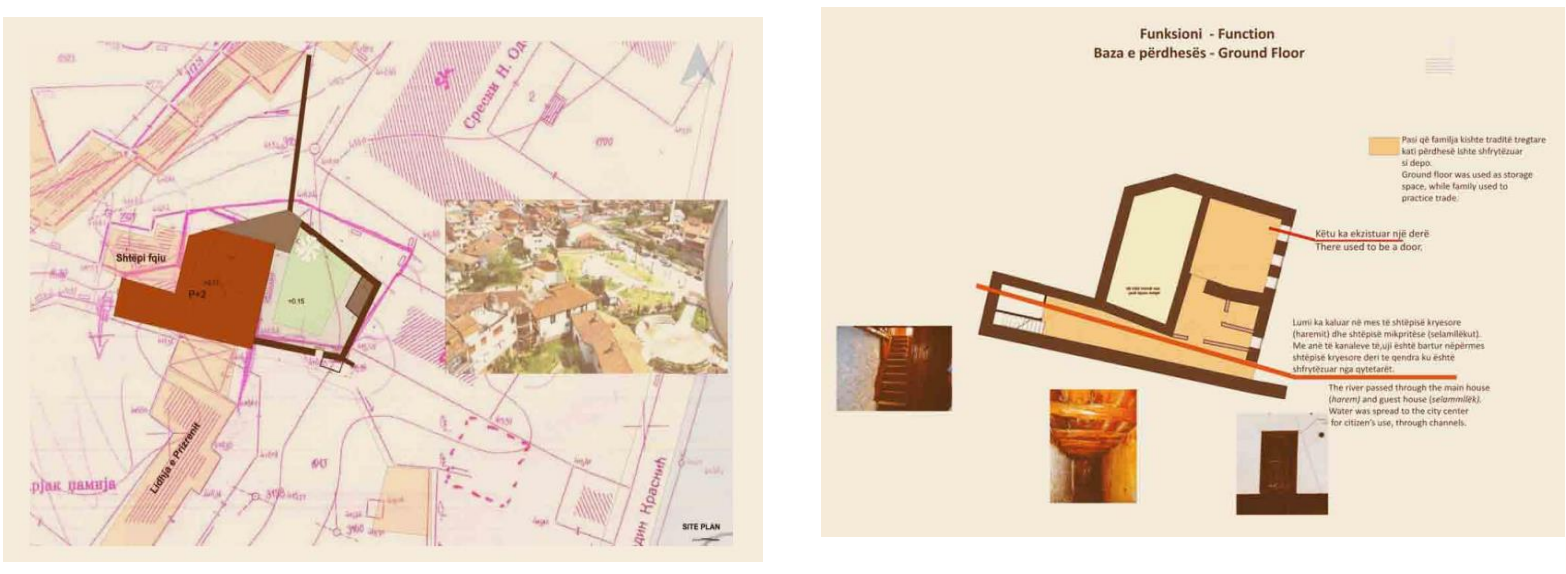
- Size and zoning: As per conservation Plan of the Prizren city, 2005, Mashkulli -house is in planned marked zone as for housing area, specified as well per height, site allowable site coverage and uses. (Fig.6.)

\subsection{Energy efficiency by simulation Analyses - Case of Mashkulli house}

House Maskulli is located in Prizren, in the southern part of Kosovo. It is a traditional Albanian house, mainly built in bricks (straw and soil mixture), where south/internal wall made from stone. The floors and roof are insulated with soil between wooden boards, windows are single glazed with wooden frames. The U-values corresponding to the different envelope elements are calculated and summarized in table 2 . This table also displays the required $\mathrm{U}$-values according to passive house standards ${ }^{1}$ for existing buildings and the amount of insulation needed to fulfill the requirements assuming the use of Rockwool 201 VARIO $(\lambda=0,034 \mathrm{~W} / \mathrm{mK})$. The current windows need to be replaced by triple glazed windows.

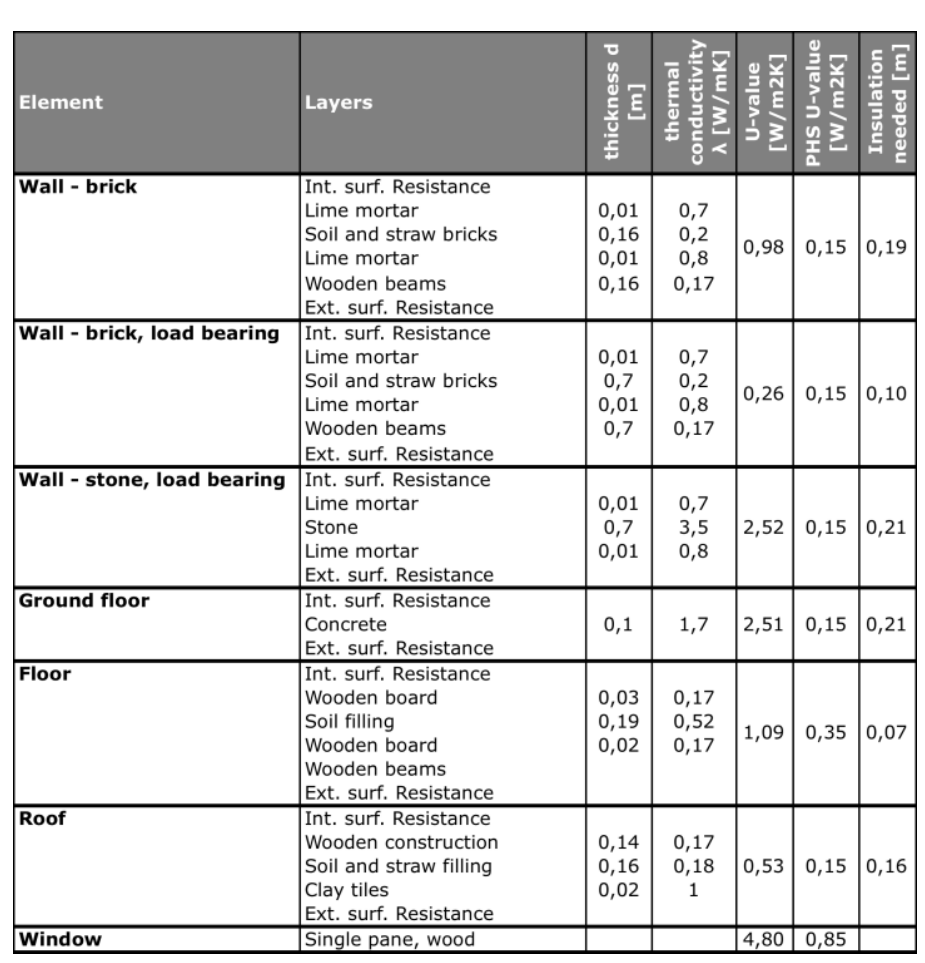

Prizren has a maritime temperate climate classified as $\mathrm{Cfb}$ according to the Köppen-Geiger classification ${ }^{2}$. The main challenge in a temperate climate is the seasonal variation between underheated and over-heated periods (Fig. 7.). This graph represents the monthly diurnal averages for Prizren with the comfortable temperature zones.

Table 2: overview of $U$-values of the existing elements, the required $U$-values according to passive house standards, and the thickness of insulation that is needed to reach these standards.

Fig.8. shows the effect of passive strategies on the indoor comfort in Prizren for the whole year, the summer and the winter. As said before and further confirmed by these graphs, the effective strategies vary with the season. The indoor temperatures are comfortable during $13 \%$ of the year. Over the whole year the effective strategies are solar shading, internal heat gains and passive solar gain. This results in $91,4 \%$ comfortable hours during the year and reduces the need for active heating systems to $45 \%$. The hours that are not comfortable occur during the summer $(8,6 \%)$, when the indoor temperature is higher than comfortable. There are other passive strategies to make these over heated periods comfortable as well, but they will have a small effect on the total $(<5 \%)$ and are therefore not considered in this simulation.

In addition to these strategies, the shape and form of the building will also affect the energy consumption ${ }^{4}$. A compact shape and no openings towards the north will result in less heat losses through the envelope. Openings towards the south can result in passive gain, but need to be shaded during the summertime to avoid overheating. Some of these strategies are already implemented in house Mashkulli. The house has a compact design, is closed towards the north, uses thermal mass for solar storage, and has a light coloured building surface to avoid overheating in the summer. 


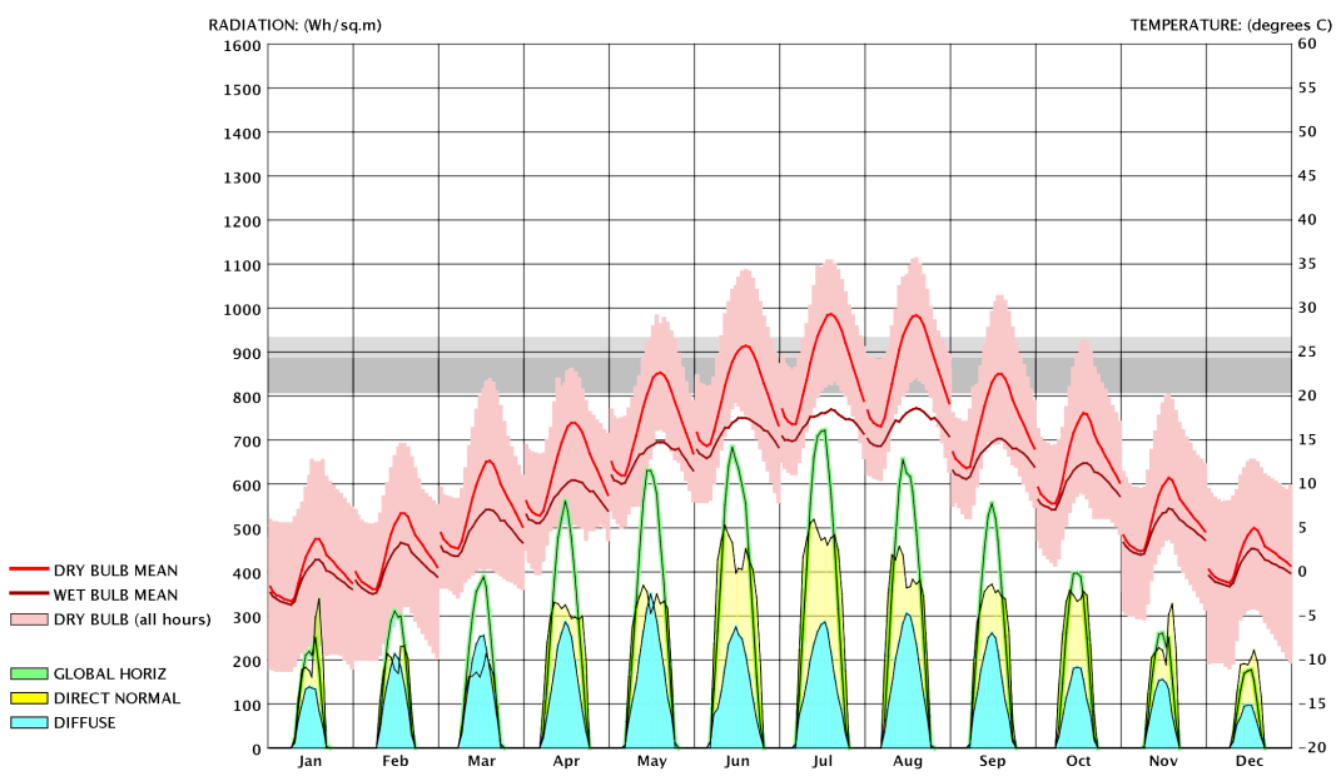

Fig.7.Monthly diurnal averages for Prizren, extracted from Climate Consultant ${ }^{3}$

The building has a natural ventilation system, but the rooms mostly have openings in one façade, which makes cross ventilation possible only when doors between rooms are opened.

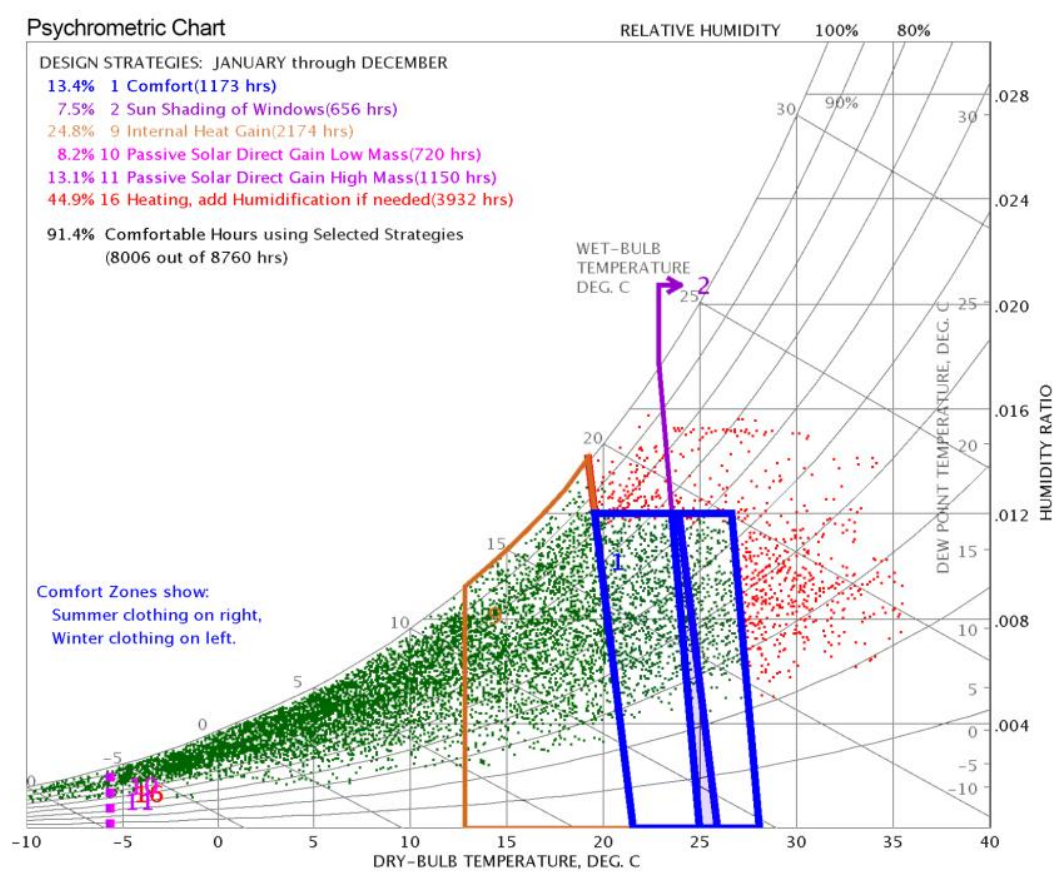

Fig. 8. psychrometric chart with the effect of passive strategies on the indoor comfort (comfortable hours of the total in percent), extracted from Climate Consultant ${ }^{3}$

Method - The building was modeled in Design Builder ${ }^{5}$. U-values of the elements were calculated assuming the thermal properties of the existing building. The climate file used for the simulation was a weather file for Prizren, extracted from Meteonorm ${ }^{6}$. The building was divided into several zones (living room, hall, kitchen, bedroom), and both occupied and unoccupied zones were used in the simulation so that the house could be evaluated as one unit. The HVAC systems in the simulation were a cooling system powered by electricity and a heating system with biomass, since Albanian houses are traditionally heated with wood. The house has no mechanical ventilation, but infiltration is high due to poor air tightness $(1,5 \mathrm{ACH})$. 
The simulation time was one year, but for better understanding of the graphs, only a typical summer and winter week are shown in the result-section. In order to evaluate the environmental performance and energy efficiency of the house itself, simulations were made both with and without the active heating/cooling systems, for both the existing house and for the refurbished house with passive house

standards. The HVAC systems were the same in both cases, but for the refurbished house, the mechanical ventilation was a fan coil system with $75 \%$ heat recovery.

\section{Results:}
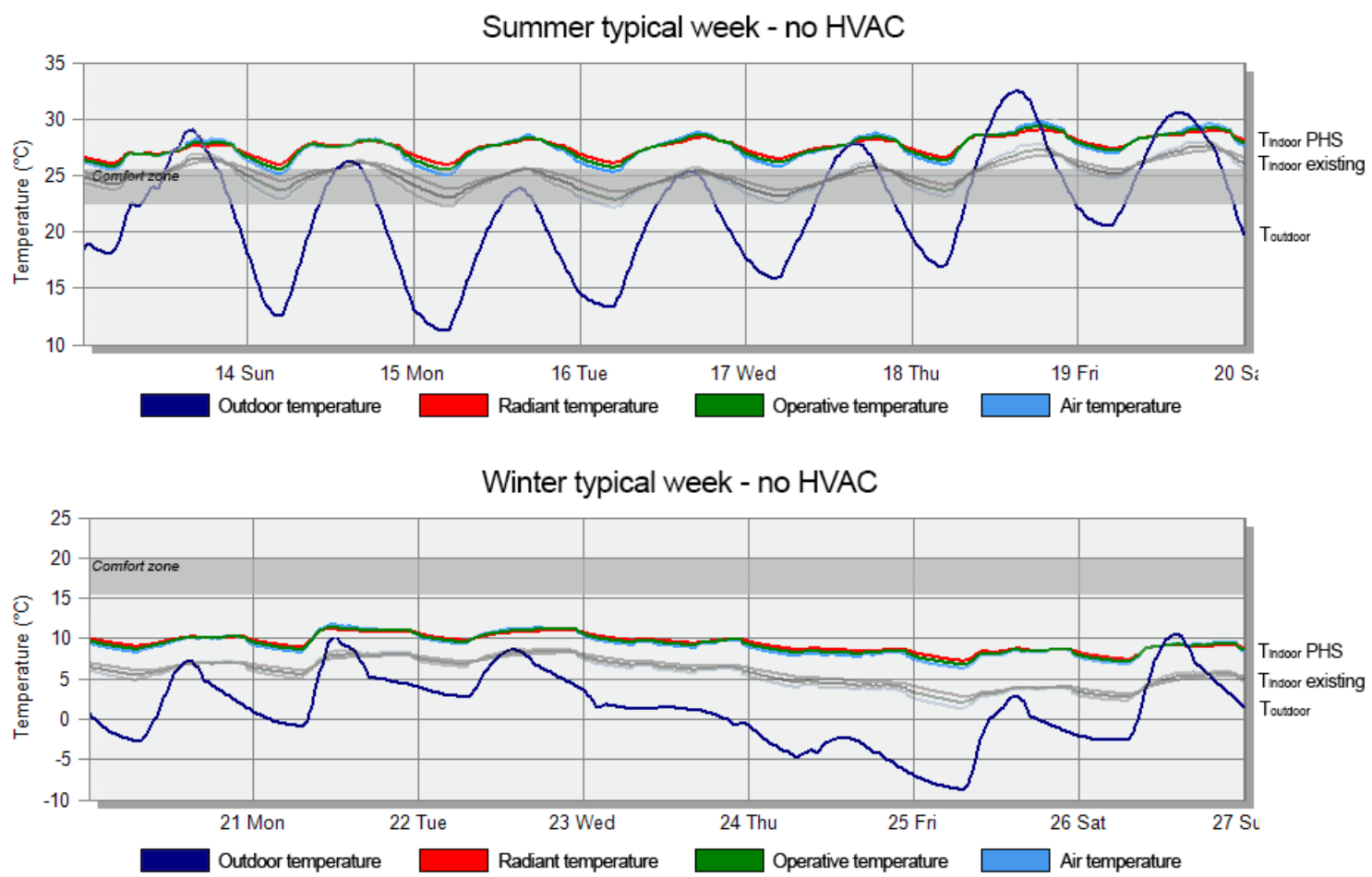

Fig. 9 Indoor temperatures when no heating or cooling systems are used in house Mashkulli for a summer and winter typical week

When the indoor temperature of the house is simulated without any heating or cooling systems, it becomes clear that the indoor temperature in the winter is much lower than the comfortable temperature in both cases. When passive house standards are applied to the house, the indoor temperature rises throughout the whole year. In the summer it is visible that the indoor temperature can be higher than the comfort temperature, but on average the indoor temperature is within the comfortable temperature range in the existing situation. However, if the house is refurbished with passive house standards, the indoor temperature in the summer becomes too high and cooling is needed to retain a comfortable indoor climate. This shows that upgrading the house to reach passive house standards is effective in the winter, but will probably result in overheating during the summer. 


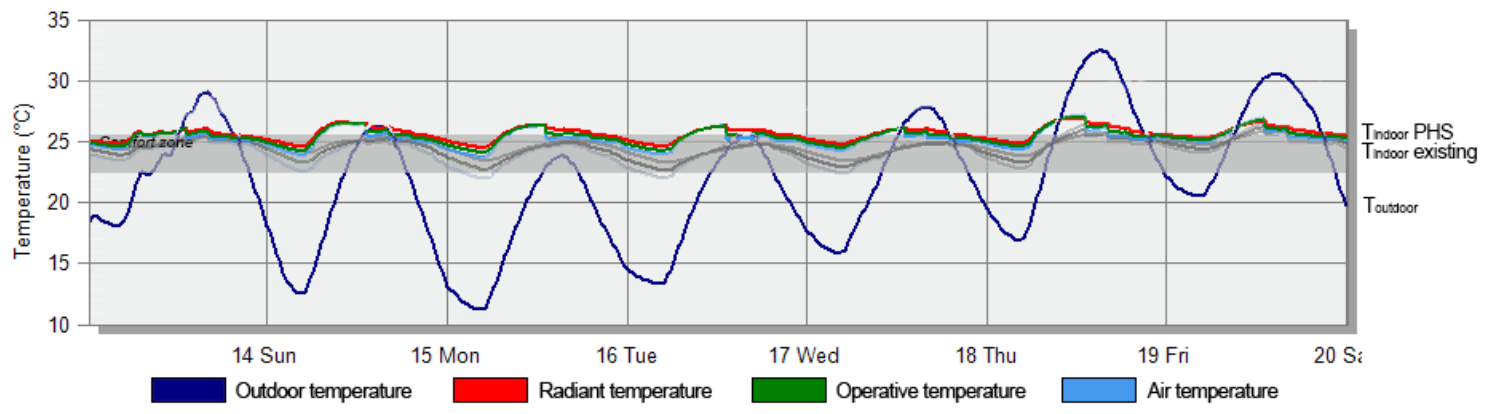

Winter typical week - HVAC

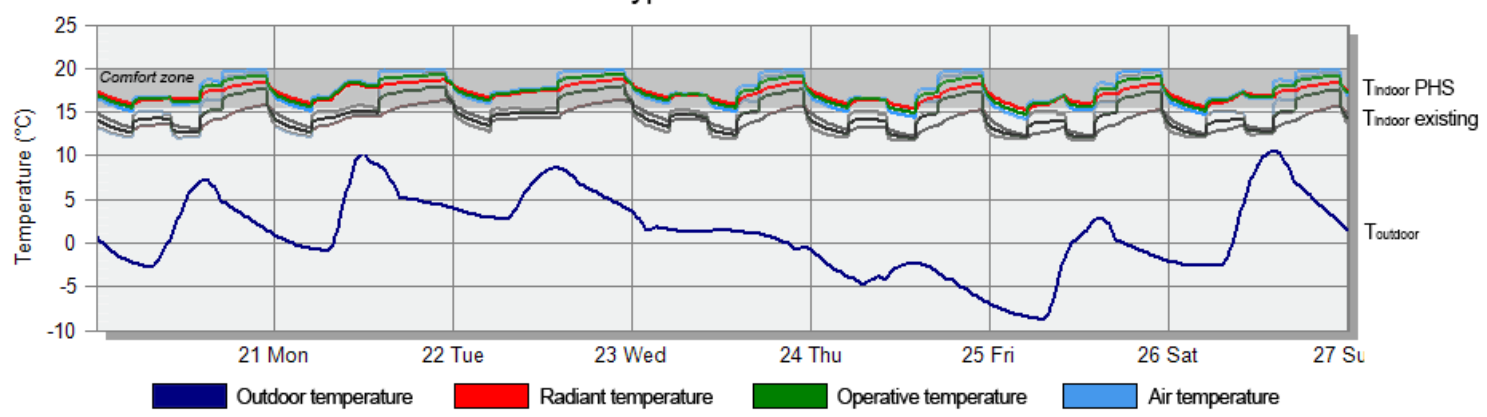

Fig. 10 Indoor temperatures when heating and cooling systems are used in house Mashkulli for a summer and winter typical week

When the indoor temperature of the house is simulated with active heating and cooling systems, it becomes clear that the indoor temperatures in the existing situation are still lower than the comfortable temperatures in the winter. The capacity of the heating system is not high enough to ensure a comfortable climate during the winter. This is because of the high heat losses due to poor thermal properties of the envelope. When passive house standards are applied, the indoor temperatures are in the comfortable zone. During the summer in both cases the temperatures are lower with HVAC systems than compared to no systems, meaning that there are cooling systems active to lower the temperature in the house.

The total energy consumption of the house is $180 \mathrm{kWh} / \mathrm{m}^{2}$ where the heating demand accounts for $140 \mathrm{kWh} / \mathrm{m}^{2}$. The total energy consumption of the house after the refurbishments is $105 \mathrm{kWh} / \mathrm{m}^{2}$ where the heating demand accounts for $62 \mathrm{kWh} / \mathrm{m}^{2}$. This is an improvement of $42 \%$ on the total energy consumption compared to the existing situation and an improvement of $55 \%$ on the heating demand.

\subsection{Interview analyses}

In total 30 interviews were conducted with well informed key people of Prizren regarding traditional housing in core historic centre of Prizren and their needs and potentials to sustainable refurbishment

i)Inhabitants; ii)Municipal officials and iii) Civil society representatives (Neighbours, owners of the craftsman shops in neighbourhood and the city of Prizren, students and professors of architecture, ethnology) researchers, NGO representatives, academia staff), with the open-ended questions.

In total 27 questions were prepared as for the questionnaire. ${ }^{8}$

\footnotetext{
${ }^{8}$ Answers were quantified in a range from -2 to +2 (-2/very bad; $-1 /$ bad; $0 /$ neutral, $+1 /$ good; $2 /$ very good $)$
} 


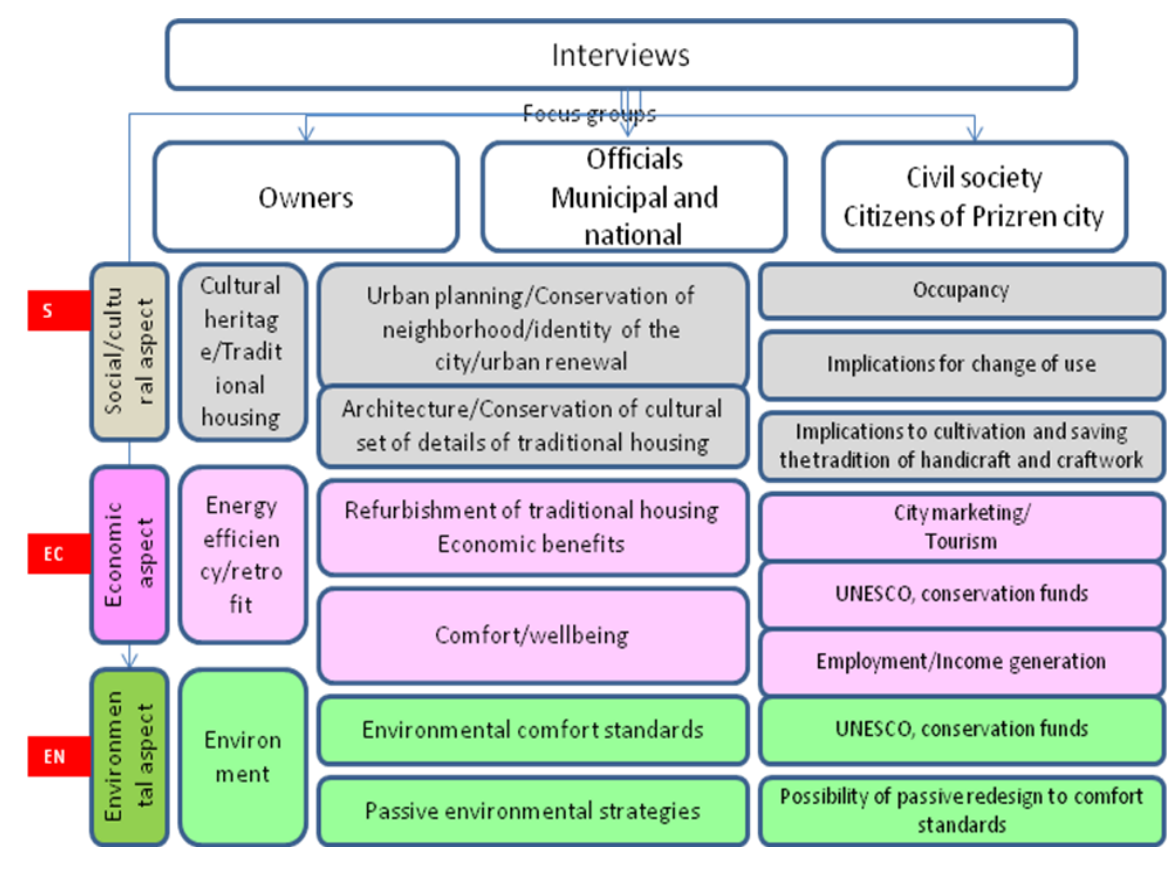

Fig. 11. Schematic presentation of the group of questions for the three target groups of interviews

The Fig.12 shows level of awareness/potentials about three aspects of sustainable refurbishment: economic and social/cultural aspect, whereas environmental aspect seen as less important.
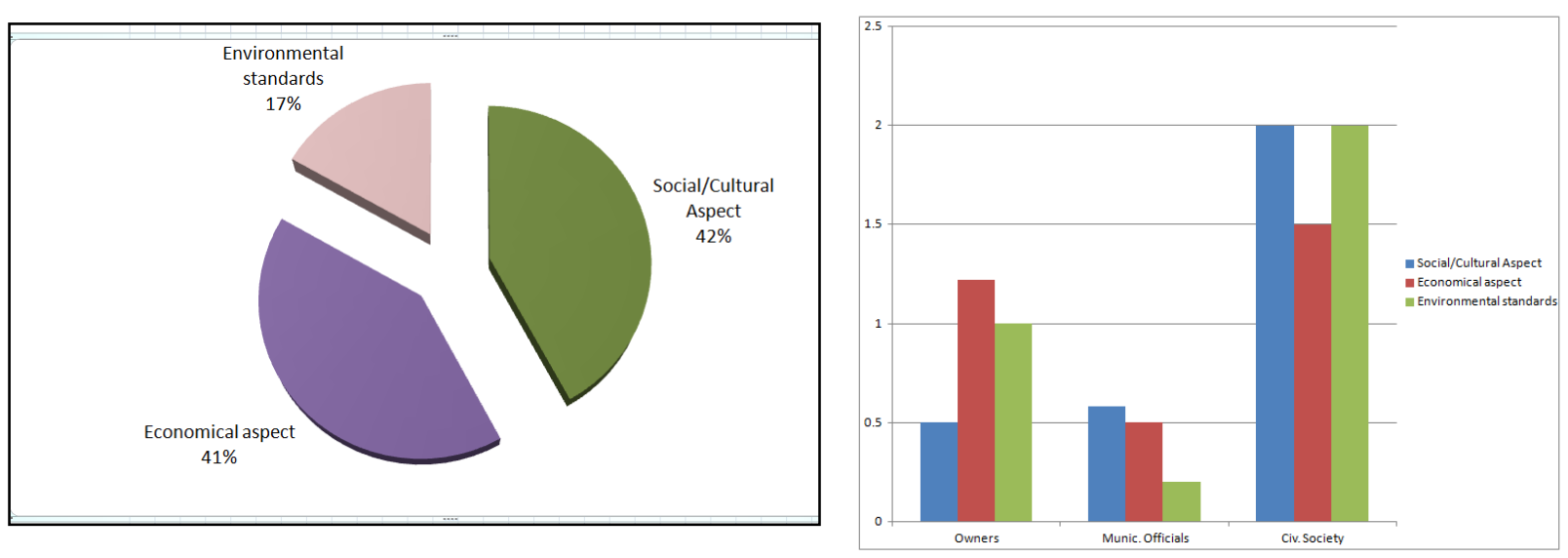

Fig. 12. Awareness/potentials of sustainable

Fig. 13. Awareness/ potentials as per group/interviews

The Fig.13 shows opinion of each target group regarding three sustainability aspects of refurbishment. The most expressing warning and enthusiasm is civil society, meaning researchers, professionals, knowers of architectural values, whereas the most un-expressing are public officials especially of the municipality of Prizren.

\section{CHAPTER 4}

\subsection{Results of analysis, conclusion and recommendation}

A.I. As per literature review, there is strong argumentation that refurbishment of traditional houses is more sustainable than rebuild or new built areas of housing, in many aspects such as cultural, societal, economic and therefore environmental.

A.II. As per Kosovo legislation and strategy review of documents regarding Energy Efficiency in Kosovo, even though housing is diagnosed as the biggest exploiter/user of energy, the policies for refurbishment/upgrading of housing are not seeing as priority of the state. Norms and standards aren't set as benchmarking for housing, though ways nor alternatives aren't set in practice (institutional, financial etc).

B.I. As per the simulation, the results show a large decrease in total energy consumption (42\%) and a decrease in the heating demand $(55 \%)$ when the house is refurbished and more passive strategies are implemented. 
B.II. As per the interview analyses, the results shows that there is a room for improvement of the decision making institutions as the main driving force to implement ability of the energy efficiency measures, refurbishment.

\subsection{Conclusion}

The main conclusions to the research questions are proven:

1. YES - By improving energy efficiency in traditional housing would be reached sustainable solution in economic, social and physical/environmental aspect;

2. NO -Legislation in Kosovo does NOT support improvement of energy efficiency in traditional housing as solution and development strategy;

3. YES - The key people of Prizren, think positively and do see energy improvement of traditional housing in Prizren/Kosovo as potential towards sustainable urban development of their city and of any city of traditional buildings.

I - The first hypothesis has been proven that: "A traditional Albanian house (such as house Mashkulli), is nowadays not energy efficient due to poor thermal properties, but the use of both passive and active strategies can improve the environmental and energy performance of the building.".

When the envelope of the house is refurbished to reach passive house standards and extra passive strategies are implemented, the total energy consumption of the house improves by $42 \%$ and the heating demand is reduced by almost 55\% compared to the existing situation. However, the heating demand is still larger than the demand required by passive house standards and therefore this house is not a passive house. It was assumed in the simulation that the house can be insulated externally and have all the windows replaced, but this might not be a realistic scenario.

II - The second hypothesis has been proven that: "By improving energy efficiency in traditional housing in Kosovo/Prizren city, would be reached sustainable solution in economic, social and physical/environmental aspect of development".

By improving the house, the environmental performance and energy efficiency of the house improves by implementing passive house strategies. In addition, these improvements will have an effect on multiple levels of sustainability. The quality of life improves, because there is a better and more comfortable indoor climate (social), the house is more energy efficient and therefore will impact the environment less (environmental), and this also results in lower energy costs (economic).

\subsection{Recommendation}

As regards to the findings to this research, the recommendations were listed as for the improvement of the implementation environment of the energy efficiency measures, refurbishment of the housing in general, whereas traditional housing in particular:

R1. Start, research and use INTL. experiences as model to traditional housing protection via Energy efficient refurbishment measures, by networking with other intl $R \& D$ institutions, using the best case lessons.

R2. To complete legal framework for EE in residential/traditional buildings, by settling of correlations in legislative framework within the area of energy, housing, spatial planning and building construction. Drafting and implementing new technical regulation on EE and changes on existing regulation on thermal energy saving in HOUSING/Traditional buildings though.

R3. Develop strategies for improvement and management in residential/traditional houses regarding Energy Efficiency E for energy efficiency followed by the appropriate raising awareness campaigns on thermal energy savings in building sector in general; 
R4. Develop innovative financing for EE investments in residential buildings through introduction of fiscal policy needed for the application of customs relief connected with efficient technologies, subsidies on energy auditing costs, energy conservation investment costs and promotional activity cost.

\section{References}

- Baker Nick V., 2009. "The handbook of Sustainable Refurbishment”, RIBA Publishing, London. ISBN: 978-1-84407-486-0

- Bere J., 2013. “An Introduction to Passive House”. RIBA Publishing, ISBN:978-185-94-6493-9

- Bokalders V., Block M., 2010. 'The Whole Building Handbook: Designing Healthy, Efficient and Sustainable Buildings". Earthscan/RIBA Publishing, London. ISBN: 9781844075232

- Brinda.G,2008, "Putting Economic Governance at the Heart of Peace building"

- Clark D., 2013. "What Colour is your Building?: Measuring and reducing the energy and carbon footprint of buildings". RIBA Publishing, ISBN:978-185-94-6447-2

- Clark.F. (2012),The Architect's Role in Urban Regeneration, Economic Development and Sustainability,

- Dalal-Clayton, B., Sadler B., 2014., "Sustainability appraisal: A sourcebook and reference guide to international experience”. Routledge, London and New York. ISBN: 978-1-84407-357-3

- DesignBuilder Software Ltd, 2015. DesignBuilder (v 4.5.0.173). [computer program] DesignBuilder Software Ltd. Available at: <http://www.designbuilder.co.uk/> [Accessed October 2015]

- Dustin, Garrett,2007,Sustainable Architecture, an overview of equitable and efficient spaces,

- Energy Design Tools, 2015. Climate Consultant (v 6.0 Beta). [computer program] University of California. Available at: <http://www.energy-design-tools.aud.ucla.edu/climate-consultant/requestclimate-consultant.php $>$ [Accessed November 2015]

- EU pillar, PISG, Energy office, 2003, “Energy strategy and policy of Kosova - white paper”, Prishtina

- http://en.wikipedia.org/wiki/Sustainable_architecture [Accessed October 2015]

- http://pcparch.com/firm/bibliography/essays/the-architect-s-role-in-urban-regeneration-economicdevelopment-and-sustainability [Accessed October 2015]

- http://pdxlivingbuilding.com/wp-content/uploads/2008/08/sustainable architecture.pdf [Accessed October 2015]

- http://wbdg.org/design/sustainable.php [Accessed October 2015]

- http://www.caes.uga.edu/departments/bae/extension/handbook/documents/permeability\%20of\%20const\% 20mat.pdf [Accessed October 2015]

- Klassen, Van den Berg, L., and Van der Meer, L.,1988, “The City: Engine Behind Economic Recovery” Euricur, Rotterdam.

- Landry, Ch., 2000, “The Creative City - a toolkit for urban innovators". Earthscan publications Ltd, London

- Lechner, N., 2009. Heating, cooling, lighting: sustainable design methods for architects. 3rd ed. Hoboken, New Jersey: John Wiley \& Sons, Inc.

- Marion B., 2013. "Residential Retrofit: 20 Case Studies". RIBA Publishing. ISBN: 978-185-94-6501-1

- MESP, 2004, “The Vision, Goals and Principles of Spatial Development in Kosova-2005-2015”, Prishtina.

- Meteotest, 2015. Meteonorm (v 7.1.6). [computer program] Meteotest. Available at: $<$ http://meteonorm.com/en/downloads> [Accessed October 2015]

- Meyer B. W. , 2013. "The Environmental Advantages of Cities: Countering Commonsense Antiurbanism”. MIT Press. ISBN: 9780262518468 
- Passive House Institute, 2013. EnerPHit and EnerPHit+i Certification Criteria for Energy Retrofits with Passive House Components. 〈http://passiv.de/downloads/03_certification_criteria_enerphit_en.pdf> [Accessed October 2015]

- UK Department of Trade and Industry report, 2003, "Cities, Regions and Competitiveness", London

- Van den Berg et al, 2004, "European Cities in the knowledge economy", Euricur, Rotterdam.

- VTT Technical Research Centre of Finland.,2012. "Sustainability and performance assessment and benchmarking of buildings -Final report”. Julkaisija -Utgivare - Publisher. ISBN: 978-951-38-7908-2

- Wikipedia, 2015. Köppen climate classification. [online] Available at: <https://en.wikipedia.org/wiki/K\%C3\%B6ppen_climate_classification> [Accessed October 2015]

- Zukin, Sh., 1995, "The Culture of Cities”. Cambridge Massachusetts, USA

\section{BIO - Dr.Sc. Elvida Pallaska}

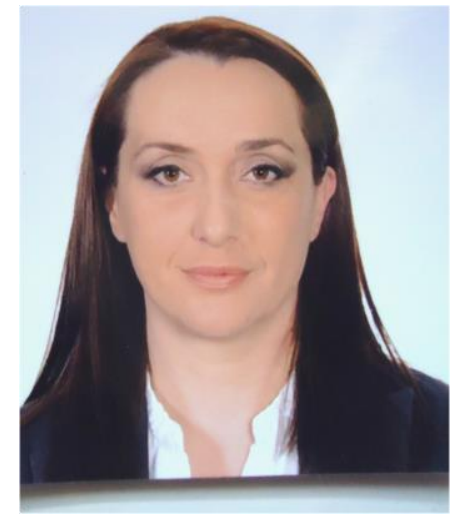

Elvida Pallaska is a lecturer at the UBT - Higher Education Institution, Department of Architecture and Spatial Plannning in Prishtina. Kosovo. Previosly lectured in College ESLG - European School of Law and Governance/Department of Real Estate and Infrastructure and State University of Tetovo, FyROM/Faculty of Applied Sciences.

She was a Senior Spatial Planner for almost 15 years in the Institute for Spatial Planning of the Ministry of Environment and Spatial Planning/Republic of Kosovo, responsible for spatial planning legislation; National Spatial Plan and Spatial Plans for specific protected areas; Researches on different urban issues.

Worked for several International humanitarian and developing organizations, responsible for management of reconstruction works in Kosovo and FyROM:

She is active in civic affairs, serving in numerous professional boards and committees; Ms. Pallaska completed her engineering/architecture studies at the University of Prishtina; Master degree taken in the University of Erasmus/Institute for Housing and Urban Studies in Rotterdam.

She completed her doctoral studies in the field of Regional Planning and Development in the Technical University of Tirana/Faculty of Architecture and Spatial Planning. 